\title{
A DEMENCIA VIZSGÁLATI ESZKÖZEI, FIZIKAI AKTIVITÁSSAL VALÓ ÖSSZEFÜGGÉSEINEK MÉRÉS-METODIKAI KÉRDÉSEI-ÁTTEKINTÉS
}

\author{
THE ANALYTICAL TOOLS OF DEMENTIA, THE RELATIONSIP BETWEEN DEMENTIA AND \\ PHYSICAL ACTIVITY - A METHODOLOGICAL APPROACH: SYSTEMATIC REVIEW
}

Makra Gabriella, Balogh László

Debreceni Egyetem, Sporttudományi Koordinációs Intézet, Debrecen

\begin{abstract}
Összefoglaló
Bevezetés: A demencia mostanára mondhatni „népbetegséggé” nôtte ki magát, így egy igen fontos kutatási területté vált. Számos vizsgálatot áttekintve, az is elfogadott tény, hogy a rendszeres fizikai aktivitás (ld. MAKRA - BALOGH, 2018; DONKA - BALOGH, 2018) inkább hat pozitívan a kognitív képességekre és a neurodegeneratív elváltozásokra, mint semlegesen, vagy negatívan. Mivel ezen betegség a kognitív képességek hanyatlását foglalja magába, elengedhetetlen, hogy kiemelt figyelmet kapjon, hogy kezelésével a megélt évek száma, valamint azok minősége növekedhessen.
\end{abstract}

Célkitüzés: Szeretnénk egy átfogó képet kapni a demencia mérésében használatos módszerekrôl, eszközökröl.

Módszer: A témához kapcsolódó szakirodalmi cikkek áttekintése, összegzése általunk meghatározott szempontok szerint (mérés típusa, mérési módszerek kapcsolata, mérések száma). Eredmények: Az általunk átvizsgált kutatásokban igen sok mérési eszközt találtunk, mely alkalmas a demencia mérésére, tesztelésére. A mérések javarész kettő, vagy több mérő eszköz együttes használatával történik, hogy minél pontosabb és komplexebb eredményt kaphassanak a demenciát illetően. Valamint az is megállapítható, hogy napjainkban több gyakorlatias mérési formát használnak, ebben a témában is és a papír-ceruza tesztek csak kísérő mérésként, megerôsítésként szerepel a kutatások többségében.

Következtetések: Megállapíthatjuk, hogy sok mérőeszköz áll rendelkezésünkre a demencia tesztelését illetően. Ezek közül kell kiválasztanunk a számunkra legmegfelelőbbet.

Kulcsszavak: demencia, demencia mérése, fizikai aktivitás, review 
Vol 3, No 1 (2020): Stadium - Hungarian Journal of Sport Sciences https://doi.org/10.36439/SHJS/2020/1/5421

\section{Abstract}

Introduction: Dementia has now grown to become a "folk disease", making it a very important area of research. After reviewing several studies, it is also accepted that regular physical activity (MAKRA - BALOGH, 2018) (DONKA - BALOGH, 2018) tends to have a positive effect on cognitive abilities and neurodegenerative disorders rather than neutrally or negatively. Because this disease involves a decline in cognitive abilities, it is imperative that special attention be given to improving the number of years of life and the quality of treatment.

Objective: We would like to get a comprehensive picture of the methods and tools used to measure dementia.

Method: Reviewing and summarizing the related articles in the literature according to the criteria we have defined (type of measurement, relation of measurement methods, number of measurements). Review.

Results: In our research, we found many measuring tools that are suitable for measuring and testing dementia. Most measurements are made using two or more measuring devices combined to provide more accurate and complex results for dementia. It can also be stated that more practical forms of measurement are used today, and in this topic, paper-pencil tests are only used as accompanying measurements, as a confirmation in most studies.

Conclusions: There are many measuring tools available for testing dementia. We have to choose the one that suits us best.

Keywords: dementia, dementia measurement, physical activity, review 


\section{BEVEZETÉS}

Egészen a 19. század végéig egyszerűen elfogadták az emberek, hogy az öregedés velejárója a feledékenység. Ugyan ismert volt a demencia jelensége, mégis csak 1907-ben fedezték fel az Alzheimer-kórt, mint a demencia egyik fő okozóját. Ez az agyi elváltozásokat okozó jelenség vélhetően már korábban is jelen volt, viszont mára már „népbetegséggé” nőtte ki magát.

„A demencia tünetegyüttes és betegségcsoport, ez utóbbi értelemben a mentális viselkedészavarok közül az organikus és szimptomatikus mentális betegségekhez tartozik. Másrészt a demencia a kognitív funkciók hanyatlásával járó, folyamatos leépülést okozó agyi tünetcsoport (ÉRSEK et al., 2010) A demencia definitív ismérveinek a BNO-10 meghatározását fogadják el. (GYARMATI, 2010)”

„A hazai előfordulási gyakoriságra főként nemzetközi felmérések alapján következtetnek. Európában a 60 év feletti lakosság 6\%-a szenved a demencia valamelyik típusában (a 90 éven felülieknél az arány közel 30\%). 2000-ben Európa országaiban 7,1 millió volt a betegek száma, ami 2050-re várhatóan 16,2 millió főre emelkedik. Évente nagyjából 4 millió új beteggel kell számolni (ÉRSEK et al., 2010). Egy rotterdami lakossági felmérés szerint az ottani életkilátásokkal rendelkező 65 éves férfiak 16, a 65 éves nők 34,5\%-a betegedik meg később demenciában. A hazai kockázat 60 éves kor felett a holland (65 éves és a feletti) értékek felénél nagyobbra, vagy a körülire (férfiak: > 8\%, ill. nők: > 17\%) becsülhető. Valószínű, hogy Magyarországon jelenleg 150 ezer főnél többen, de 300 ezer főnél kevesebben szenvednek különféle eredetű és súlyosságú demenciában. (GYARMATI, 2010)"

Ez a betegség köztudott, hogy súlyos terheket ró nemcsak a betegekre, hanem a családra, a körülöttük élőkre is. Így mondhatni hat számjegyűre nőtt a közvetlen és közvetett módon érintettek száma ilyen téren. Azon túl, hogy genetikai okai is lehetnek ennek a betegségnek, manapság olyan életvitelt folytatunk, ami mellett nem meglepő, hogy az „agyunk felmondja a szolgálatot”. Ha ezen az úton haladunk 30 éven belül megháromszorozódik a demenciában szenvedők száma a világon. Tehát fontos, hogy megoldást találjunk erre és kezelni tudjuk ezt.

Korábbiakban elkészített szakirodalmi áttekintésünk (MAKRA - BALOGH, 2018), mely a fizikai aktivitás és a kognitív képességek kapcsolatát vizsgálja számos nemzetközi kutatás elemzése alapján megállapította, hogy a fizikai aktivitás és a kognitív képességek között kölcsönkapcsolat található.

„Az idősebb korosztály tekintetében az 5. ábra szemlélteti az eredményeket a fizikai aktivitás és az időskori megbetegedések kapcsán (az általunk átvizsgált 20 kutatás alapján). 


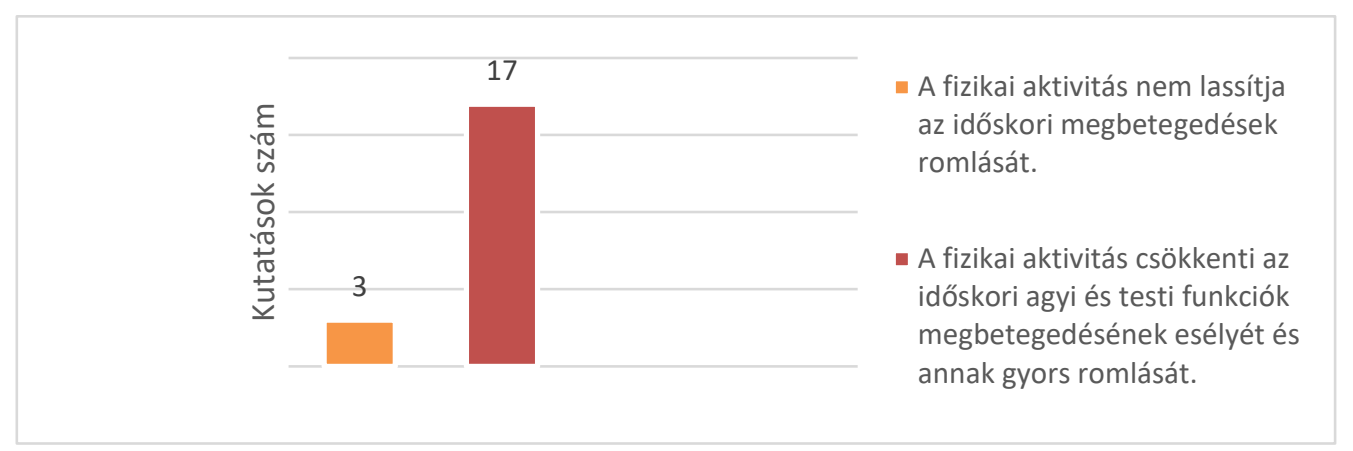

1. ábra: A fizikai aktivitás és az időskori megbetegedések kapcsolata Forrás: saját ábra

A kutatások 85\%-a azt bizonyítja, hogy segíti az esetleges időskori betegségek kialakulásának és romlásának lassítását, megállítását. (MAKRA - BALOGH, 2018)" „Az utóbbi évtizedben világossá vált, hogy a rendszeres testedzés nagyon kedvezően befolyásolja az agy működését, és nagyon fontos prevenciós és terápiás eszköz lehet az agyvérzés, Alzheimer és Parkinson betegségek esetében is. (RADÁK, 2007)" Mindezen adatok arra hívják fel figyelmünket, hogy a demencia kapcsán is érdemes hangsúlyt fektetni a fizikai aktivitásra, annak minőségére és mennyiségére, hisz gyógymódként szolgálhat akár a demencia, akár egyéb megbetegedések kapcsán.

A demencia megállapításához számos kritériumnak kell teljesülnie, melyek magukba foglalják az érzelmi, értelmi és társas képességek romlását, valamint annak fokát. Leggyakoribb tünete az emlékezetzavar. Kezdetben csak a rövid távú memória sérül, valamint a felidézés és megjegyzés. Később viszont a hosszú távú memóriában is elhalványodnak az emlékek, így számos készség és képesség elveszhet. A fent említett kritériumok vizsgálatára több módszer is létezik és használatos. Ezen módszerek egyre dinamikusabban fejlődnek. Ahhoz, hogy a megfelelő vizsgálati módszert tudjuk alkalmazni fontos, hogy legyen egy komplex képünk, ismeretünk a manapság használt demencia mérő eszközökről és azok validitásáról. Ezen szakirodalmi áttekintés elkészítésének fő célja tehát, hogy egy aktuális képet kapjuk a jelenlegi mérőeszközökről, melyek használatosak a tudományos életben, ezen belül is a fizikai aktivitással kapcsolatos kutatások területén.

\section{ANYAG ÉS MÓDSZER}

Dokumentumelemzésünkhöz az alábbi internetes forrásokon keresztül kerestünk az adott témával foglalkozó cikkeket:

- Taylor \& Francis Online,

- Google-Scholar, 
- PubMed,

- Researchgate,

- ScienceDirect.

Kutatásunk túlnyomó többségében nemzetközi cikkeket dolgoztunk fel, angol nyelven, hogy minél átfogóbb képet kaphassunk az adott témában.

A szakirodalmi áttekintésünket a következő metódus szerint végeztük. Első és legfontosabb szempontunk a mérő eszközök összegyűjtése volt (1). Ezen túl arra is figyelmet fordítottunk, hogy egy adott kutatás, vizsgálat során hány mérési formát alkalmaztak a demencia, a kognitív hanyatlás, vagy az Alzheimer-kór diagnosztizálására, súlyosságának felmérésére (2). Mindezek mellett vizsgáltuk a mérések fajtáját (3). Itt két nagy csoportot különítettünk el. Egyik a papír-ceruza tesztek, ahol a vizsgált személynek egy kérdőívet kell kitöltenie, melyben különböző, a már fentebb említett kritériumokra kiélezett kérdésekre kell válaszolnia (3a). A másik pedig a gyakorlatias vizsgálati formák voltak, mely akár a vizsgálatot végző segítségével, néhány esetben invazív beavatkozás (vérvétel) segítségével, vagy számítógépes program használatával, interaktívan történik (3b). Mindezen szempontokon túl igyekeztünk arra is figyelmet fordítani, hogy azoknál a cikkeknél, ahol a fizikai aktivitás és a kognitív képességek kapcsolatát mérték, milyen eszköz/eszközök segítségével állapították meg a kognitív képességek állapotát, a demencia mértékét. (4).

Összesen 30 cikk adatait dolgoztunk fel, mely tartalmaz több review-t is, ennek köszönhetően több mint 250 kutatás anyagát sikerült átvizsgálni.

\section{Kutatási kérdéseink és hipotéziseink}

[K1] Hány féle mérési eszköz létezik a demencia vizsgálatára?

(H1) Feltételezzük, hogy csekély a demencia mérésére alkalmas vizsgálati módszerek száma és fajtája.

[K2] Van e konkrét standardizált demencia mérő eszköz, vagy több módszer együttesen alkalmaznak a következtetések levonásához?

(H2) Feltételezzük, hogy több módszer alkalmazásával kaphatjuk meg ezt a komplex diagnózist.

[K3] Gyakrabban használnak e papír-ceruza teszteket a demencia vizsgálásához, mint egyéb gyakorlatias módszereket?

(H3) Feltételezzük, hogy gyakrabban használnak papír-ceruza teszteket a demencia tesztelése során. 
[K4] Melyek a leggyakrabban használt mérőeszközök, amit demencia és a rendszeres testedzéssel való kapcsolat vizsgálata során alkalmaztak?

(H4) Feltételezzük, hogy a demencia és a rendszeres testedzéssel való kapcsolat mérése során javarészt gyakorlatias mérőmódszereket alkalmaznak.

\section{EREDMÉNYEK}

Eredményeinket a fent említett négy fő szempont szerint szeretném ismertetni.

Az általunk átvizsgált kutatások a következő mérési módszereket használták a demencia, Alzheimer-kór és a kognitív hanyatlás méréséhez.

$>$ Vienna Test System (VTS)

$>$ Wechsler Memory Scale (WMS)

$>$ Consortium to Establish a Registry for Alzheimer's Disease (CERAD)

$>$ Boston Naming Test (BNT)

$>$ Mini-Mental State Examination (MMSE)

$>$ Rosen Drawing Test

$>$ Controlled Oral Word Association Test (COWA)

$>$ Digit Symbol Subtest (DSST)

$>$ Hopkin Verbal Learning Test

$>$ Informant Questionnaire on Cognitive Decline in the Elderly (IQCODE)

$>$ Rivermead Behavioral Memory Test

$>$ Cognitive Abilities Screening Instrument (CASI)

$>$ National Adult Reading Test

$>$ Symbol Digital Modalities Test (SDMT)

$>$ Hasegawa Demencia Skála

$>$ Cambridge Neuropsychological Test Automated Battery (CANTAB)

> Montreal Kognitív Felmérés (MoCa)

$>$ Paired Associates Learning (PAL)

$>$ Addenbrook Kognitív Vizsgálat

$>$ Trial Making Test

$>$ Geriátriai Depresszió Skála (GDS)

$>$ Clinical Dementia Rating Scale (CDR)

$>$ BDNF szint mérése (vérben)

$>$ Victoria Stroop Test

$>$ East Boston Story

$>$ Selective Reminding Test

$>$ Benton Visual Retention Test (BVRT)

$>$ Mattis Dementisa Rating Scale

$>$ Wechsler similarities 
$>$ Delay word recall test

$>$ Word fluency test

$>$ Digit Symbol Substitution Test (DSST)

$>$ Symbol Digital Modalities Test

$>$ Verbal Fluency

$>$ Vocabulary Test

$>$ CogEvo

$>$ Digital Ordering

$>$ Alpha Span

$>$ Rey Auditory Verbal Learning Test (RAVLT)

Számszerűsítve, közel 40 mérési módszert jegyezhetünk le. Ezek között van papír-ceruza teszt, számítógépes tesztrendszer és invazív beavatkozás is.

Az általunk átvizsgált szakirodalmak, melyek a demencia és a fizikai aktivitás kapcsolatát vizsgálják a következő eszközök segítségével mérték a vizsgált alany demencia szintjét/mértékét:

- Mini-Mental State Examination (MMSE)

- Cambridge Neuropsychological Test Automated Battery (CANTAB)

- Symbol Digital Modalities Test

- Verbal Fluency

- Victoria Stroop Test

- Trial Making Test

- Delay word recall test

- Wechsler Memory Scale (WMS)

- Symbol Digital Modalities Test (SDMT)

Megállapítható, hogy a fent említett eszközök egyike sem a szokásos papír-ceruza tesztek közé tartozik. Ezen műszerek segítségével valid, realtime állapotfelmérés lehetséges, így az eredmény is pontosabb lehet.

Szeretnék a fent említett mérési módok közül néhányat kiemelni és részletezni azok működését.

Vienna Test System (VTS)

„A SCHUHFRIED világelsőként fejlesztette ki pszichológiai tesztrendszerét, a Vienna Test System-et (VTS). A számítógépes pszichológiai mérés egykori úttörőjét mára a terület szakértőjeként tartják számon. Évente több mint 13 millióan használják a Vienna Test System-et kiválasztás és alkalmassági mérések, vezetői készségek vizsgálata során, neuropszichológiai, klinikai és kutatási célokra, illetve élsportolók tesztelésére."1

\footnotetext{
${ }^{1}$ https://www.schuhfried.hu/R\%C3\%B3lunk/
} 


\section{Cambridge Neuropsychological Test Automated Battery (CANTAB)}

„A kognitív értékelések felbecsülhetetlen értékű eszközök az egyes agyi funkciók szerepének megértéséhez számos rendellenesség és szindróma körében; betekintést nyújt a mögöttes okokba, meghatározza a legkorábbi tünetek felderítésének lehetőségeit és felméri az agyi egészség javítását célzó beavatkozások hatásait.

Az eredetileg a Cambridge-i Egyetemen kifejlesztett Cambridge Neuropsychological Test Automated Battery (CANTAB) magában foglalja a kognitív funkciók rendkívül érzékeny, pontos és objektív méréseit, összevetve az ideghálózatokkal.

A CANTAB tesztek bebizonyították, hogy érzékenyek a neuropszichológiai teljesítmény változásaira, és tartalmazzák a munkamemória, a tanulás és a végrehajtó funkció vizsgálatát; vizuális, verbális és epizodikus memória; figyelem, információfeldolgozás és reakcióidő; társadalmi és érzelmek felismerése, döntéshozatal és válaszok ellenőrzése."2 Informant Questionnaire on Cognitive Decline in the Elderly (IQCODE)

A fenti kérdőív, magyar nevén az időskorúak kognitív hanyatlásról informáló kérdőív, egy olyan mérési eszköze a demenciának, ami idős ember rokonai vagy közeli kapcsolatban lévők tölthetnek ki a vizsgált személlyel kapcsolatban. Mindez annak érdekében történik, hogy megállapíthassuk, a vizsgált személy kognitív képességek terén milyen változásokon megy keresztül.

\section{BDNF szint mérése (vérben)}

„A BDNF (agyi eredetű neurotróf faktor) kiemelkedő szerepet játszik a megismerés és a memória modulálásában. A BDNF egy neurotrofin, amely olyan fehérjék családjába tartozik, amelyek elősegítik a neuronok túlélését, működését és fejlődését." ${ }^{3}$ Ezen ismeretek és a fent említett információk birtokában megállapíthatjuk, hogy a BDNF egy igen fontos előre jelzője, szintmérője lehet a demenciának is. Ez az invazív eljárás orvosok segítségével mérhető paraméter, melyet a vérből nyerhetjük.

\section{Victoria Stroop Test}

Ez a teszt a kognitív rugalmasságot méri. A feladat nehézsége három egymást követő vizsgálat során növekszik. Három stimuláló kártya jelenik meg egymás után (1) színes pontok, (2) közös szavak, amelyek ugyanolyan színűek, mint a pontok, és (3) színes szavak nyomtatva, amelyek nem felelnek meg a tinta színének. Az első kártyánál az alanyokat felkérjük, hogy egyszerűen nevezze meg az egyes pontok színét, balról jobbra, az egymást követő sorrendben. A második kártyánál az alanynak meg kell neveznie a tinta színét, nem pedig a szót. Az utolsó kártyához a résztvevőt felkérjük, hogy nevezze meg a

\footnotetext{
${ }^{2}$ https://www.cambridgecognition.com/cantab

${ }^{3}$ https://www.ncbi.nlm.nih.gov/pmc/articles/PMC6358753/
} 
leírt színt, és ne a szó színét. Az egyes feladatok elvégzése során rögzítésre kerülnek a hibák száma és a feladat elvégzéséhez szükséges idő. ${ }^{4}$

\section{East Boston Story Memory Test}

Ez a módszer egy történet segítségével méri a kognitív képességeket, azon belül is az emlékező képességet. A vizsgáló elmond egy három mondatos történetet. Ezt követően azonnal kikérdezésre kerülnek az alanytól az előbbiekben elhangzottak. Ha két hibánál többel sikerül csak visszahívni a mondatokat, körülbelül két perc feladatmegoldást követően újra kikérdezésre kerül az elején elhangzott történet.

\section{Montreal Kognitív Felmérés (MoCa)}

„A Montreal Kognitív Felmérést (MoCA) az enyhe kognitív károsodás gyors kiszűrésére fejlesztették ki. Különféle kognitív területeket mér fel: figyelem és koncentráció, végrehajtó funkciók, emlékezet, nyelv, vizuális konstrukciós képességek, fogalmi gondolkodás, számolás és orientáció. A MoCA felvétele körülbelül 10 percet vesz igénybe. A maximálisan elérhető pontszám 30 pont; 24 vagy annál több pont tekinthető normál értéknek." 5

Arányaikat tekintve, több az eszközökkel végzett mérési módszer, mint a papírceruza tesztek. Ugyanakkor azt is megfigyelhettük az általunk átvizsgált tesztek körében, hogy javarészt kettő, vagy több mérési formát alkalmaztak egy diagnózis, vagy következtetés levonásához.

Ezen tények ismeretében a hipotéziseink a következő képen teljesültek:

(H1) Feltételezzük, hogy csekély a demencia mérésére alkalmas vizsgálati módszerek száma és fajtája.

Az általunk átvizsgált 20 szakirodalmi áttekintése során közel 40 darab mérési eszközt sikerült megismernünk. Ezen adatoknak köszönhetően ez a hipotézisünk nem igazolódott.

(H2) Feltételezzük, hogy több módszer alkalmazásával kaphatjuk meg ezt a komplex diagnózist.

Ahogy fent is említettem, több szinte minden esetben kettő, vagy több módszert alkalmaztak a diagnózis felállításához. Így ez a hipotézisünk beigazolódott.

(H3) Feltételezzük, hogy gyakrabban használnak papír-ceruza teszteket a demencia tesztelése során.

\footnotetext{
${ }^{4}$ https://www.uvic.ca/socialsciences/psychology/research/clinic/stroop.php

${ }^{5}$ https://adoc.tips/montreal-kognitiv-felmeres-moca-alkalmazasi-es-pontozasi-ins.html
} 
A kigyűjtött és fentiekben felsorolt mérési eszközök közül arányait tekintve kevesebb a kimondottan papír-ceruza tesztek száma, mint a műszeres mérési módszereké. Ebből kifolyólag ez a hipotézisünk nem igazolódott.

(H4) Feltételezzük, hogy a demencia és a rendszeres testedzéssel való kapcsolat mérése során javarészt gyakorlatias mérőmódszereket alkalmaznak.

Az általunk átvizsgált cikkek alapján ez az állítás beigazolódott.

\begin{tabular}{|c|c|c|c|c|}
\hline \multicolumn{2}{|r|}{ KUTATÁSI KÉRDÉS } & \multicolumn{2}{|r|}{ HIPOTÉZIS } & \multirow{2}{*}{$\begin{array}{c}\text { EREDMÉNY } \\
\text { NEM } \\
\text { IGAZOLÓDOTT BE }\end{array}$} \\
\hline [K1] & $\begin{array}{l}\text { Hány féle mérési } \\
\text { eszköz létezik a } \\
\text { demencia } \\
\text { vizsgálatára? }\end{array}$ & (H1) & $\begin{array}{l}\text { Feltételezzük, hogy } \\
\text { csekély a demencia } \\
\text { mérésére alkalmas } \\
\text { vizsgálati módszerek } \\
\text { száma és fajtája. }\end{array}$ & \\
\hline [K2] & $\begin{array}{l}\text { Van e konkrét } \\
\text { standardizált } \\
\text { demencia mérö } \\
\text { eszköz, vagy több } \\
\text { módszer együttesen } \\
\text { alkalmaznak a } \\
\text { következtetések } \\
\text { levonásához? }\end{array}$ & $(\mathrm{H} 2)$ & $\begin{array}{l}\text { Feltételezzük, hogy több } \\
\text { módszer alkalmazásával } \\
\text { kaphatjuk meg ezt a } \\
\text { komplex diagnózist. }\end{array}$ & BEIGAZOLÓDOTT \\
\hline [K3] & $\begin{array}{l}\text { Gyakrabban } \\
\text { használnak e papír- } \\
\text { ceruza teszteket a } \\
\text { demencia } \\
\text { vizsgálásához, mint } \\
\text { egyéb gyakorlatias } \\
\text { módszereket? }\end{array}$ & (H3) & $\begin{array}{l}\text { Feltételezzük, hogy } \\
\text { gyakrabban használnak } \\
\text { papír-ceruza teszteket a } \\
\text { demencia tesztelése } \\
\text { során. }\end{array}$ & $\begin{array}{c}\text { NEM } \\
\text { IGAZOLÓDOTT BE }\end{array}$ \\
\hline [K4] & $\begin{array}{l}\text { Melyek a } \\
\text { leggyakrabban } \\
\text { használt } \\
\text { mérőeszközök, amit } \\
\text { demencia és a } \\
\text { rendszeres } \\
\text { testedzéssel való } \\
\text { kapcsolat vizsgálata } \\
\text { során alkalmaztak? }\end{array}$ & (H4) & $\begin{array}{l}\text { Feltételezzük, hogy a } \\
\text { demencia és a rendszeres } \\
\text { testedzéssel való } \\
\text { kapcsolat mérése során } \\
\text { javarészt gyakorlatias } \\
\text { mérőmódszereket } \\
\text { alkalmaznak. }\end{array}$ & BEIGAZOLÓDOTT \\
\hline
\end{tabular}

2.ábra: Eredmények összegzése

Forrás: saját ábra 


\section{MEGBESZÉLÉS}

Összegzésképpen megállapítható, hogy darabszámban és típusát tekintve is sok féle mérési eszköz létezik a demencia mérésére, tesztelésére. Azt is elmondhatjuk, hogy egyre több és népszerűbb a műszeres eszközökkel történő mérési módszerek alkalmazása, mely igaz a fizikai aktivitás hatásait vizsgáló kutatásokra is.

Ugyanakkor fontos ezen eszközök helyes megválasztása, kipróbálása ahhoz, hogy a számunkra szükséges paramétereket mérje és ezekből pedig valid, komplex állapotot állapíthassunk meg.

A publikáció elkészítését az EFOP-3.6.1-16-2016-00022 „Debrecen Venture Catapult Program” projekt támogatta. A projekt az Európai Unió támogatásával, az Európai Szociális Alap társfinanszírozásával valósult meg.

A publikáció elkészítését a 2014-2020 - GINOP 2.3.2.-15-2016-00062 projekt támogatta. A projekt az Európai Unió támogatásával, az Európai Szociális Alap társfinanszírozásával valósult meg. 


\section{IRODALOMJEGYZÉK}

Alexandra R. B., Arany A. C., Jámbor I., Szabó K., Mile M., Makra G., Csiki Z., Balogh L., \& Papp, G. (2019). Investigation on the Immunological Effects of Regular Physical Activity. STADIUM - Hungarian Journal of Sport Sciences, 2, (1), 1-15. DOI: https://doi.org/10.36439/sjsc.v2i1.2929

Balogh L., Makra G., Donka D., Pucsok JM., Bacsne Baba E., Kiss B., Csiki Z., Nagy A., \& Papp G. (2019). Comparative analysis of the effects of regular exercise on immunoregulatory and cognitive abilities in young and elderly adults (abstract). Bunc V.. 24th Annual Congress of the EUROPEAN COLLEGE OF SPORT SCIENCE - BOOK OF ABSTRACTS. (2019) ISBN:9783981841428 pp. 592-592 Paper: ISBN 978-3-9818414-2-8

Banes D.E., Yaffe K., \& Satariano W.A. (2003). A longitudinal study of cardiorespiratory fitness and cognitive function in healthy older adults. J Am Geriatr Soc, 51,(4), 459-65. DOI:10.1046/j.1532-5415.2003.51153.x

Beishon LC., Batterham A.P., Quinn T. J., Nelson C. P., Panerai R. B., Robinson T., \& Haunton V. J. (2019). Addenbrooke's Cognitive Examination III (ACE-III) and mini-ACE for the detection of dementia and mild cognitive impairment. Cochrane Database Syst Rev. 2019 Dec 17;12:CD013282. DOI: 10.1002/14651858.CD013282.pub2

Dagmar N., Alexander S. (2016). Effect of 3-months home based exercise program on chandes of cognitive functioning in order adults living in old people's home. Volume 56: Issue 1, 18 May 2016, 16-29. DOI: https://doi.org/10.1515/afepuc2016-0002

Donka D., Balogh L. (2018). Fizikai aktivitás és a sztressz a stresszmérés metodológiai problémáinak vizsgálata - review. ISSN 2631-0910 ISBN 978-963-490-063-4, Debreceni Egyetem Sporttudományi Koordinációs Intézet, 130-140.

Hogervorst E, Clifford A, Stock J, Xin X, \& Bandelow S. (2012). Exercise to Prevent Cognitive Decline and Alzheimer's disease: For Whom, When, What, and (most importantly) How Much?. J Alzheimers Dis Parkinsonism, 2, (117). doi:10.4172/21610460.1000e117 
Egerházi A., Berecz R., Bartók E., \& Degrell I. (2007). Automated Neuropsychological Test Battery (CANTAB) in mild cognitive impairment and in Alzheimer's disease. Prog Neuropsychopharmacol Biol Psychiatry. 13, 31, (3):746-51. Epub 2007 Jan 16. DOI:10.1016/j.pnpbp.2007.01.011

Soares FC, de Oliveira TC, de Macedo LD, et al. (2014). CANTAB object recognition and language tests to detect aging cognitive decline: an exploratory comparative study. Clin Interv Aging, 10, 37-48. Published 2014 Dec 19. doi:10.2147/CIA.S68186

Gauthier S., Reisberg B., Zaudig M., Petersen RC., Richie K., Broich K., Belleville S. Brodaty H., Bennett D., Chertkow H., Cummings JL., de Leon M., Feldman H., Ganguli M., Hempel H., Scheltens P., Tierney MC., Whitehouse P., \& Winbald B. (2006). Mild cognitive impariment. Lancet, 15, 367, (9518), 1262-70. DOI: 10.1016/S0140-6736(06)68542-5

Grass-Kapanke B., Busmane A., Lasmanis A., Hoerr R., \& Kaschel R. (2011). Effects of Ginkgo Biloba Special Extract EGb $761 ®$ in Very Mild Cognitive Impairment (vMCI). NM> Vol.2 No.1, March 2011, PP 48-56. DOI: 10.4236/nm.2011.21007

Gyarmati A. (2010). Demensek a szociális ellátórendszerben.

Hoffmann I. (2011). Demencia és nyelv-az Alzheimer-kór korai nyelvi előjelei. URI: http://real.mtak.hu/id/eprint/12039

Hoffmann K, Sobol N.A., \& Frederiksen K.S. (2015). Moderate-to-high intensity physical exercise in patients with Alzheimer's disease: a randomized controlled trial. J Alzheimers Dis, 50, (2), 443-53. doi: 10.3233/JAD-150817. DOI: 10.3233/JAD-150817

Ichii S., Nakamura T., Kawarabayashi T., Takatama M., Ohgami T., Ihara K., \& Shoji M. (2019). CogEvo, a cognitive function balancer, is a sensitive and easy psychiatric test battery for age-related cognitive decline. Geriatr Gerontol Int, 20, (3), 248-255. doi: 10.1111/ggi.13847. Epub 2019 Dec 18. DOI:10.1111/ggi.13847 
Jorm AF. (2004). The Informant Questionnaire on Cognitive Decline in the Elderly (IQCODE): a review. Int Psychogeriatr, 16, (3), 275-93. DOI:

$10.1017 / \mathrm{s} 1041610204000390$

Jorm AF., Scott R., Cullen JS., \& MacKinnon AJ. (1991). Performance of the Informant Questionnaire on Cognitive Decline in the Eéderly (IQCODE) as a screening test for dementia. Cochrane Database Rev, 2016(11): CD011333. doi: 10.1002/14651858.CD011333.pub2

Jorm AF., Scott R., \& Jacomb PA. (1989). Assessment of cognitive decline in dementia by informant questionnaire. Psychol Med. 19, (4),1015-22. DOI: $10.1017 / \mathrm{s} 0033291700005742$

Makra, G., Balogh, L. (2018). Examination of the Relationship Between Physical Activity and Cognitive Skills. STADIUM - Hungarian Journal of Sport Sciences, 1(1), 1-15. https://doi.org/10.36439/sjsc.v1i1.2924

Morales J.M., Gonzalez M. J. I., Bermejo F., \& Del S. T. (1995). The screening of mild dementia with a shortened Spanish version of the „Informant Questionnaire on Cognitive Decline in the Elderly". Alzheimer Dis Assoc Disord, 9,(2),105-11. DOI:10.1097/00002093199509020-00008

Radák Zs., Troma F. Berkes I., Goto S., Mimura T., Posa A., Balogh L., Boldogh I., Higuchi M., \& Koltai E. (2018). Exercise effects on physiological function during aging. Free Radic Biol, 20, (132), 33-41. doi: 10.1016/j.freeradbiomed.2018.10.444.

Sidiarto LD, Kusumoputro S, Samino S, Munir R, \& Nugroho W. The efficacy of specific patterns of movements and brain exercises on the cognitive performance of healthy senior citizen in Jakarta. Med J Indones [Internet]. 2003Aug.1 [cited 2020Mar.8];12(3):155-61. Available from: http://mji.ui.ac.id/journal/index.php/mji/article/view/107

Sirály E., Szita B., Kovács V., Csibri É., Hidasi Z., Salacz P., Szabó Á., Maros V., Hanák P., Pataki B., \& Csukly G. (2013). Az enyhe kognitív deficitben szenvedők differenciálása az 
Vol 3, No 1 (2020): Stadium - Hungarian Journal of Sport Sciences

https://doi.org/10.36439/SHJS/2020/1/5421

egészséges idős populációtól neuropszichológiai tesztek segítségével. Neuropsycholopharmacologia Hungarica, 15,(3), 139-146.

Souza LC., Antunes MS., Filho CB., Del Fabbro L., de Gomes MG., Goes AT., Donato F., Prigol M., Boeira SP., \& Jesse CR. (2015). Flavonoid Chrysin prevents age-related cognitive decline via attenuation of oxidative stress and modulation of BDNF levels in aged mouse brain. Pharmacol Biochem Behav, 134, 22-30. doi: 10.1016/j.pbb.2015.04.010.

Susumu A., Satoru K., Hatsue W., Kazuo K., Fumiko F., Tomoko T., Machiko I., Yasuo T., Naotaka I., Kazutada W., \& Hiroaki N. (2002). Animal model of dementia induced by entorhinal synaptic damage and partial resoration of cognitive deficits by BDNFF and carnitine. J Neurosci Res, 1, (3), 519-27. DOI: 10.1002/jnr.10443

Takao S., Hiroyuki S., Hyuma M., Takehiko D., Saisuke Y., Kota R., Yuya A., Kazuki U., Sangyoon L., \& Hyuntae P. (2012). Effects of multicomponent exercise on cognitive function in older adults with amnestic mild cognitive impairment: a randomized controlled trial. BMC Neurol, 12, 128. doi: 10.1186/1471-2377-12-128

Ted K. S. N., Cyrus S. H. H., Wilson W. S. T., Ee H. K., \& Roger C. M. H. (2019). Decreased Serum Drain-Derived Neurotrophic Factor (BDNF) Levels in Patients with Alzheimer's Disease (AD): A Systematic Review and Meta-Analysis. Int J Mol Sci. 20, (2), 257. doi: 10.3390/ijms20020257

Vermeer SE., Prins ND., den Heijer T., Hofman A., Koudstaal PJ., \& Breteler MM. (2003). Silent Brain Infarcts and the Risk of Dementia and Cognitive Decline. N. Engl J Med, 27, 348, (13), 1215-22. DOI: 10.1056/NEJMoa022066

Volosin M., Janacsek K., \& Németh D. (2013). A Montreal Kognitív Felmérés (MoCa) magyar nyelvű adaptálása egészséges, enyhe kognitív zavarban és demenciában szenvedő idős személyek körében. Psychiatria Hungarica, 28, (4). 370-392. ISSN 0237-7896.

Williams JW, Plassman BL, Burke J, Holsinger T, \& Benjamin S. (2010). Preventing Alzheimer's Disease and Cognitive Decline. Evidence Report/Technology Assessment No. 193. (Prepared by the Duke Evidence-based Practice Center under Contract No. HHSA 
Vol 3, No 1 (2020): Stadium - Hungarian Journal of Sport Sciences

https://doi.org/10.36439/SHJS/2020/1/5421

290-2007-10066-I.) AHRQ Publication No. 10-E005. Rockville, MD: Agency for Healthcare Research and Quality.

Xiangfei M., Carl DA. (2012). Education and Dementia in the Context of the Cognitive Reserve Hipothesis: A Systematic Review with Meta-Analyses and Qualitative Analyses. PLoS One, 7, (6), e38268. doi: 10.1371/journal.pone.0038268

Yágüez L., Shaw KM., Morris R., \& Matthews D. (2010). The effects on cognitive functions of a movement-based intervention in patients with Alzheimer's type dementia: a pilot study. Int J Geriatr Psychiatry, 26, (2), 173-81. doi: 10.1002/gps.2510.

Yasutake C., Kuroda K., Yanagawa T., Oramura T., \& Yonade H. (2006). Serum BDNF, TNF$\alpha$ and IL-1 $\beta$ levels in dementis patients. Eur Arch Psychiatry Clin Neurosci, 256, (7), 4026. DOI: $10.1007 / \mathrm{s} 00406-006-0652-8$

Yurko MK., McCarthy D., Rom D., Nelson BE., Ryan A., Blackwell A., Salem N., \& Stedman M. (2010). Beneficial effects of docosahexaenoic acid on cognition in age-related cognitive decline. Alzheimers Dement, 6, (6), 456-64. doi: 10.1016/j.jalz.2010.01.013.

\section{INTERNETES HIVATKOZÁSOK}

1. https://www.schuhfried.hu/R\%C3\%B3lunk/

2. https://www.cambridgecognition.com/cantab

3. https://www.ncbi.nlm.nih.gov/pmc/articles/PMC6358753/

4. https://www.uvic.ca/socialsciences/psychology/research/clinic/stroop.php

5. https://adoc.tips/montreal-kognitiv-felmeres-moca-alkalmazasi-espontozasi-ins.html

Letöltéseik dátuma: 2020. január 5. 